\title{
Family Entrepreneurship Orientation in Family Owned SMEs: A Key Resource for Internationalization?
}

\author{
Alicja Hadryś-Nowak
}

\section{A B S T R A C T}

Objective: The main goal of this article is to find the answer to the questions: what is the nature of the internationalization of family businesses from Poland? Do they internationalize ad hoc or do they plan an internationalization strategy? Which resources are needed for the internationalization process?

Research Design \& Methods: The author used qualitative approach with CATI (Computer Assisted Telephone Interview), PAPI (Paper \& Pen Personal Interview) and CAII (Computer Assisted Internet Interview) methods. 420 questionnaires were used in the statistical analysis.

Findings: This study focuses on the evaluation of entrepreneurship orientation as the main resource of the internationalization nature (ad hoc or a strategic plan) of family businesses from Poland and measured it through the four elements proposed by Covin and Slevin (1989): Innovation, Proactivity, Autonomy and Risk.

Implications \& Recommendations: To internationalise, family business families need to apply entrepreneurship orientation, especially proactiveness towards new challenges, and strategic planning and tools.

Contribution \& Value Added: The research provides evidence of a higher degree of EO in the behaviour of a family. More successful family businesses are in international markets. They also have a challenge oriented culture, which means that such companies are oriented towards new ventures, new relations, new solutions and new markets. But they plan new challenges using the strategic approach.

\begin{tabular}{|c|c|}
\hline Article type: & research paper \\
\hline Keywords: & $\begin{array}{l}\text { family businesses; internationalization; entrepreneurship orientation; } \\
\text { resource-based view }\end{array}$ \\
\hline JEL codes: & ( \\
\hline Received: 1 & Revised: 26 January 2018 \\
\hline
\end{tabular}

\section{Suggested citation:}

Hadryś-Nowak, A. (2018). Family Entrepreneurship Orientation in Family Owned SMEs: A Key Resource for Internationalization?. Entrepreneurial Business and Economics Review, 6(2), 153-169. https://doi.org/10.15678/EBER.2018.060208 


\section{INTRODUCTION}

Internationalization is one of the most complex achievements for every company. Nevertheless, international economy is getting more and more integrated in the proceeding decrease of obstacles in the exchange market and constant progress in the technological field (Lu \& Beamish, 2001). Thus, starting internationalization seems to be a strategy needed for the further development of the company. Considering the globalization of markets, even family companies, historically tending to be concentrated on the local market, can be forced to expand externally (Donckels \& Frohich, 1991; Floren, 2001; Gallo \& Estape, 1992; Gallo \& Garcia-Pont, 1993; Gallo \& Sveen, 1991; Graves \& Thomas, 2006; Okoroafo, 1999). The easiest and the widest definition of internationalization is every kind of business activity taken by the company abroad. It is believed that the conception of the company internationalization process makes an exceptional opportunity to run the company in external markets, granted that the external market manifests strong differences in comparison to the local environment (Fernandez \& Nieto, 2005). Internalization strategy shows the company's activity in the external area. In the internationalization strategies, the existing (or not) correlation between the firm's characteristic, internationalization and ways of external expansion is crucial. As far as internationalization as such was described and examined by many of the authors, there is relatively little knowledge about internationalization in the context of the family-owned business (McKibbin \& Pistrui, 1997). Special features of the family-owned business result in a desire to maintain the control over the company in family's hands (family ownership structure), an aversion to take an excessive risk and a long time perspective, whose activities can determine both benefits and threats of the external expansion taken. Ownership plays a special role in international business, and it can be a factor stimulating the internationalization of firms (Wach, 2017). In family businesses the family ownership plays a crucial role.

The culture of the organisation in the company, which is often a reflection of the system of values in the owner's family, formal and informal engagement of the family, attachment to tradition and drawing from the experience of older generations make the internationalization strategies in those companies theoretically different from the internationalization in non-family-owned business (Coviello \& Munro, 1995; De Chiara \& Minguizzi, 2002; Gankema, Snuif, \& Van Dijken, 1997; Leonidu, 2004; Manelova, Brush, Edelman, \& Greene, 2002; McDougall \& Oviatt, 1996; Wolff \& Pett, 2000; Hadryś-Nowak, 2013). The main goal of this article is to find the answer to the question: what is the nature of internationalization of family businesses from Poland? Do they internationalize ad hoc or do they plan an internationalization strategy? The Polish context is very interesting because with the collapse of the old regime in 1989, the outburst of entrepreneurship resulted in the creation of numerous family businesses which became the backbone of the blossoming free-market economy (Bednarz, Bieliński, Nikodemska - Wołowik, \& Otukoya, 2017). Most of Polish family businesses are still in the first generation phase, so called 'founder stage'. The first succession process is happening. Researchers from Poland reveal that family firms are less internationalized than the rest, however, some researchers show that family firms listed on the stock exchange are more internationalized (Daszkiewicz \& Wach, 2014; Wach \& Wojciechowski, 2014).

What resources are needed for the internationalization process? Many authors also point to the need to increase the knowledge of the key factors that enable SMEs to be 
successful on international markets (e.g. Knight \& Cavusgil, 2004; Zahra, Ireland, \& Hitt, 2000). This study focuses on one of these elements, Entrepreneurship Orientation (EO), which refers to the processes, practices, and decision-making activities that lead to new developments for the company (Lumpkin, 1996). It is considered an important resource in order to accelerate the internationalization process (Barney, 2011), and it is especially important for SMEs (Lumpkin, 1996). Despite this importance, and although there is abundant literature on both EO and business internationalization, there is very little research regarding the relationship between these two concepts (Wach, 2015). This study investigates how different dimensions of EO contribute to the internationalization nature of family owned businesses. To be able to meet the goal, the author used CATI (Computer Assisted Telephone Interview), PAPI (Paper \& Pen Personal Interview) and CAll (Computer Assisted Internet Interview) methods. The collected material was analysed in the form of tables, discussed and verified. Two questionnaires containing errors were excluded from the whole set of questionnaires collected. The remaining 420 questionnaires were used in the statistical analysis. Earlier studies (Okoroafo, 1999; Child, Hong, \& Wong, 2002; Erdener \& Shapiro, 2005; Olivares-Mesa \& Cabrera-Suárez, 2006; Kontinen \& Ojala, 2012a; Graves \& Thomas, 2008; Claver, Rienda, \& Quer, 2007; Kontinen \& Ojala; 2010b, Muñoz-Bullón \& Sánchez-Bueno, 2012; Muñoz-Bullón \& Sanchez-Bueno; 2011; Lin, 2012) indicate that a decision on the internationalization nature in family owned comapnies is determined by a number of factors related to the business, the competitive position of the company (Gallo \& Sveen, 1991; Gallo \& Pont, 1996; Yeung, 2000; Tsang, 2001, 2002; Zahra, 2003; Sciascia, Mazzola, Astrachan, \& Pieper, 2012a, 2012b; Fernández \& Nieto, 2006; Carr \& Bateman, 2009; Donckels \& Fröhlich, 1991; Kim, Kandemir, \& Cavusgil; 2004) and very strongly depends on family related features (Menendez-Requejo, 2005; Graves \& Thomas 2006; Claver, Rienda, \& Quer, 2009; Davis \& Harveston, 2000; Byrom \& Lehman, 2009; Calabrò, Mussolino, \& Huse, 2009). To meet the aim of the article, first the internationalization in context of family businesses is discussed. Then, based on the proposed theoretical framework research hypothesis are evaluated. Based on research results discussion is elaborated. The research was conducted in 2015. It is not representative of the whole Polish family business population.

\section{LITERATURE REVIEW}

\section{Internationalization and Family Businesses}

The term internationalization can be described as the process of increasing involvement of international activity across borders (Welch \& Luostarinen, 1988). The amount of cross -border activities of a firm can therefore be expressed by its degree of internationalization (Oesterle, Richta, \& Fish, 2013). Other definitions define internationalization as a strategy process with the aim of growth (Dana, Welpe, \& Ratten, 2008). However, it is argued that the main difference between internationalization and alternate strategies of growth is that an organization transfers or sources its products, services or resources across borders (Dana et al., 2008). Various internationalization theories have been developed in order to explain the internationalization behaviour of firms, however with a somewhat different focus. Some look at transaction costs, the role of entrepreneurs or the influence of relationships, while others looks at it as a stepwise process that evolves over time. All the 
above stated theories require firms to commit resources to their internationalization. Johanson and Vahlne (1977) describe internationalization to be a stream of decisions. In the internationalization process a firm has to take a large amount of decisions, including financial decisions, as the expansion process requires substantial capital. For instance, Koch (2001) researched different aspects of the internationalization decision process amongst others the market entry mode selection, which involves committing financial resources. This research was grounded on the basis of a wide range of influencing factors which are categorised into internal, external and both mixed factors, that is both internal and external. Regarding the internal factors, the author studied the firm size in terms of their resources, which resulted in the conclusion that industry-specific resource demands have critical influence in the entry mode choice of a firm. So for instance, a fully owned subsidiary, which is very favourable for firms in terms of control, requires much more investment and involves higher risk than exporting. Khemakhem (2010) explains foreign operations to be a trade off between the cost of resources committed and control over the operation. However, whether commitment is tangible or intangible, it can involve large financial investments (Johanson \& Vahlne, 1977; Figueira-de-Lemos, Johanson, \& Vahlne, 2011). Johanson and Vahlne (2006) note in their paper that the incremental process mainly focuses on learning and commitment building, which they determine as important components in the business process. If increasing knowledge and commitment evolve successfully, the next stage is characterised by greater investments, which also includes more risk and control. In terms of the network perspective, this can also be related to relationship commitment, as a firm might be willing to invest a lot of resources in order to establish and maintain the relationship. The critical issues found by the authors are the aspects of cost, time and uncertainty involved. This leads to the definition of relationships being an asset resulting from investments (Johanson \& Vahlne, 2006). Therefore, a critical aspect in the internationalization process is the necessary resource commitment in terms of investments. At the beginning of the nineties an innovative concept appeared in strategic management. It is called the resource-based view of the firm. Knowledge is more and more often perceived as a kind of the company's 'anchor' in a turbulent environment. As a consequence of an increase in the rate of change in the market environment, a lot of companies have discarded the idea of basing their strategy on a particular market segment. Instead, numerous companies have started to look inside their own organisations, basing their strategy on their resources and competencies. This phenomenon can be characterised as a supply approach (resource-based theory approach). So far, the question of outstanding market results has been explained according to the market and product analysis (Porter, 1991). The economists paid more attention to the environment and less to the company's inside. In contrast to the finding that the sector structure determines competitive advantage (Porter, 1991), the resource-based theory suggests that having unique resources can be the source of competitive advantage (Barney, 1991). Company's knowledge and organisational procedures are important sources of competitive advantage. The resource-based theory states that the future of the company depends on the optimal use and maintenance of unique abilities: fundamental competencies. Analysing market or product quality according to this theory does not provide enough information on the company growth potential. Above all, fundamental competencies include intangi- 
ble assets, such as knowledge and abilities, which produce financial results. Tangible assets, such as buildings, perform auxiliary function towards fundamental competencies. Therefore, a research question arises: Which resources of a family enterprise influence the nature of the internationalization of family owned businesses from Poland? Very valuable resources of family enterprises, which are their essence, are for sure commitment and the presence of the next generation (Björnberg \& Nicholson, 2012). The international strategy undertaken by a firm will include the scale, scope and speed of its internationalization. The scale of firm internationalization is the extent to which the company relies on foreign sales. This indicates the decreasing dependency the firm has on its home market in favour of its international markets. Therefore, the scale of internationalization shows the extent to which a firm's sales have been developed outside of their home market. This is a good indicator of a firm's increased dependency on their foreign activities (Hilmersson, 2013). The second is the scope of internationalization. This refers to the number of markets that SMEs choose to enter, it denotes the international geographic reach of a firm's business (Hashai, 2011; Lu \& Beamish, 2001). By operating in many different markets, firms can learn from diverse circumstances and environments, and leverage this experience in new markets to aid international performance (Hilmersson, 2013). The speed of internationalization refers to the rapidity at which firms spread their international activities between different country markets. It assesses the dynamic aspect of the growth strategy. Most literature on the subject focuses on the time it takes from the inception of the firm to the start of internationalization, where a short time is treated the same as a high speed of internationalization. This 'born global' literature also only focuses on the start phase, how quickly firms enter more than one market and how quickly they spread their operations is neglected. Hilmersson (2013) however, provides a measure to analyse the speed of internationalization, by dividing the distance covered (markets entered) by the time it takes to cover this distance. To conclude, internationalization strategy is based on several decisions made, depending on resource commitment. Based on the RBV, some literature has found the importance of three interrelated factors for venturing, which are internal resources, entrepreneurship orientation and external factors (Jones, 1999; Coviello \& Munro, 1997; Westhead, 2001). International venturing is a type of business development, for which entrepreneurship is considered a fundamental driver (Covin \& Slevin, 1991; Lumpkin, 1996).

The starting point for the study of the internationalization of SMEs is recognizing that SMEs are not simply smaller versions of large corporations (Shuman \& Seeger, 1986; Pagarkar, 2008). It is argued that operating in a globalised environment is more complex for SMEs than for large companies (Gary, 2000), since any initiative related to foreign markets will use a greater share of resources in an SME. Further, in the event of failure, the impact of such an initiative on an SME is of much more importance, and thus it entails a higher risk (Pagarkar, 2008; Buckley, 1999; Lu \& Beamish, 2001). Some authors call this effect resource disadvantage and scale disadvantage for SMEs compared to their global rivals, both of which affect their possibilities of resilience (Yip, Biscarri, \& Monti, 2000). SMEs suffer a shortage of managerial resources (Qian, 2002), both in terms of quantity and of the quality needed for internationalization. Consequently, they may not perform systematic global scanning and may lack the information necessary for exploiting international opportunities (Buckley, 1999). To cope with this, SMEs tend to take short-cuts in decision-making and information gathering, which can be disastrous (Buckley, 1999). Also, 
SMEs in general do not have specialised managers for international operations and their administrative procedures are underdeveloped (Aharoni, 1966; Buckley, 1999; Van Hoorn, 1979). In addition, internationalization increases the need for coordination and communication among different units within and outside the firm and across regions (Qian, 2002), further stretching the thin managerial resources of many SMEs. Some authors have found that managerial expertise and competence, together with lack of information, were the top two difficulties faced by small technology based firms in internationalization (Karagozoglu \& Lindell, 1998). On the other hand, it is arguable that SMEs have some competitive advantages, such as greater flexibility to respond to clients' needs, and adaptability to serve small market niches. Moreover, internationalization may have some positive effects for SMEs, such as enabling them to increase the use of their production capacity, as well as providing learning opportunities when working to satisfy different customers' needs and facing the diverse competition of export markets (Pangakar, 2008; Kostova \& Roth, 2002; Zahra, Irlanda, \& Hitt, 2000). Through the process of internationalization, an SME may find it easier to build a network of contacts that will support its growth strategy (Gary, 2000; Knight \& Cavusgil, 1996). Similarly, it can be argued that the ability to carry out international expansion may not be solely related to a business size or to a business age. Rather, and especially for SMEs, the human capital of the entrepreneur and the internal resources of the firm may influence the competitive strategies pursued, as well as their performance (Reynolds, 1987; Romanelli, 1989; Bates, 1998; Kalleberg \& Leicht, 1991; Westhead, 1995b; Gimeno, Folta, Cooper, \& Woo, 1997). To sum up, despite the limitations and challenges that SMEs face in their internationalization processes, this activity may enable them to learn and improve their performance (Loth \& Parks, 2002). Therefore, and given the critical nature of international ventures for SMEs, there is still a need for further research on the factors that contribute to their success.

\section{Entrepreneurship Orientation}

Entrepreneurship orientation (EO) refers to the activities that lead to new business growth achieved by the marketing of new products to current markets or the existing products to new markets. This view emerges from a strategic - choice perspective (Child, 1972), which asserts that new entry opportunities can be successfully undertaken by 'purposeful enactment' (Van dr Ven \& Poole, 1995). According to Miller (1983) and Covin and Slevin (1989), a firm's EO is defined by the intention and actions of key players in the business, who engage in a dynamic generative process aimed at new venture creation. Entrepreneurial orientation is a broader sense of entrepreneurship (Gaweł, 2013). The key dimensions that characterise EO include: 1) the propensity to act autonomously, 2) the willingness to innovate and take risks, and 4) proactive relative to marketplace opportunities (Covin \& Slevin, 1991). Autonomy refers to the independent action of an individual or a team to bring forth an idea or a vision and carrying it through to completion. In general, it means the ability and a will to be self-directed in the pursuit of opportunities. (Covin \& Slevin, 1989). Innovation reflects a firm's tendency to engage in and support new ideas, novelty, experimentation, and creative processes that may result in new products, services, or technological processes (Miller \& Fried, 1978). Essentially the definition that Miller and Fried adopted when they defined risk taking as 'the degree to which managers are willing to make large and risky resource commitments, i.e., those which have a reasonable chance of costly failures' (Miller \& Fried, 1978, p. 923). Miller and Fried argued that the proactivity of a firm's 
decisions is determined by answering the question, 'Does it shape the environment (high score) by introducing new products, technologies, administrative techniques, or does it merely react' (Miller \& Fried, 1978). Some authors argue that the successful new entry may also be achieved when only some of these factors are operating (Kilby, 1971). EO can be considered an important resource for domestic and international activities (Barney, 2011) one that can boost the internationalization process. In the case of SMEs, which try to develop their leadership, deploy resources and build an effective strategy for internationalization, EO could be a valuable, unique and difficult to imitate resource on which to base competitive advantage. It could even be the most valuable resource for a young company to grow and reach a stage that allows its survival (Lumpkin, 1996) especially considering the likely scarcity of other resources in SMEs as noted above. Lumpkin (1996) following Covin and Slevin (1991) argues that EO is fundamental for business development. For SMEs Lumpkin considers that the processes of decision making for a new entry and its implementation are basically in the hands of their leaders. Although the concept of entrepreneurship has been applied to many different levels (individuals, groups and organisations), entrepreneurship is often thought to be within the purview of individuals only, because it is frequently associated with the introduction of a revolutionary invention (Kilby, 1971). In the case of SMEs the individual level is very important. Some authors contend that 'the small business firm is simply an extension of the individual who is in charge' (Lumpkin, 1996, p. 138). In family firms, the firm is very often the extension of the family. The experiences, skills, and competences of entrepreneurs (family) are generally regarded as key factors influencing business survival and development (Storey, 1994). Consequently, it can be argued that the entrepreneurship capability of the leaders of SMEs is a good representation of the company's EO. Vatne (1995) presented a conceptual model for the internationalization of SMEs engaged in manufacturing activities, suggesting that the territorial environment could influence a firm's internal resources. Also, social networking and the entrepreneur's quality influence a firm's ability to identify, acquire and use external resources for product development, production, and promotion. Given the differences between SMEs and large companies, especially regarding tangible resources, the use of intangibles by SMEs, such as managerial capabilities, is probably distinctive and specific for business success (Knight, 2009).

Based on the above considerations, the author takes into consideration the following factors:

- family firm internationalization nature as planned internationalization strategy or ad hoc process,

- factors related to the business, like: the age and size of the business,

- family related features and entrepreneurship orientation: 1) the propensity to act autonomously, 2) the willingness to innovate and take risks, and 3) a tendency to be aggressive toward competitors, and 4) proactive relative to marketplace opportunities.

\section{MATERIAL AND METHODS}

The population unit represented by the analysed sample was a family business understood as a business in which the majority of decision-making rights are in the possession of the natural person(s) who established the firm, or in the possession of the natural person(s) 
who has/have acquired the share capital of the firm, or in the possession of their spouses, parents, child, or children's direct heirs, moreover at least one representative of the family or kin is formally involved in the governance of the firm (European Family Business Foundation) through the owner or co-owner.

The analysed population was assessed on the basis of information concerning the number of family businesses as $36 \%$ (Lewandowska et al., 2016) of the total number of firms in Poland. The size of the sample obtained during the research was greater than the assumed minimum one which allowed to generalise analyses ${ }^{1}$ and was at the level of 422 family businesses. In order to efficiently conduct the research, a survey method was adopted and was carried out along three paths using CATI (Computer Assisted Telephone Interview) ${ }^{2}$, PAPI (Paper \& Pen Personal Interview) ${ }^{3}$ and CAll (Computer Assisted Internet Interview $)^{4}$. The survey was conducted in 2015.

The main hypothesis, which became an introduction to further analyses, assumes that family businesses when they internationalize, regardless of whether they plan it or do it ad hoc, concern also characteristics and activities connected with the family firm specificity. This assumption is complemented by five auxiliary hypotheses in which it was essential to recognize relationships between dependent variables (family firm internationalization nature) and independent variables (family enterprise metrics and entrepreneurial orientation):

1. Family firm internationalization nature (IS) is connected with the age of a business (AB).

2. Family firm internationalization nature (IS) is connected with the size of a business (SB).

3. Family firm internationalization nature (IS) is connected with the family propensity to act autonomously (IP).

4. Family firm internationalization nature (IS) is connected with the family willingness to innovate and take risks (EE).

5. Family firm internationalization nature (IS) is connected with family proactiveness relative to marketplace opportunities (VA-GM).

\section{RESULTS AND DISCUSSION}

Each of the auxiliary hypotheses made was broken into two detailed ones, connected with the family firm internationalization nature (here: planned internationalization strategy PS or internationalization ad hoc-AH). A chi-squared test was used as a verifying tool of the hypotheses made. As a result of that, each detailed hypothesis was divided into the next two ones: the null hypothesis stating that there is no relationship between the analysed variables and the alternative hypothesis stating there is a relationship between them. The test results for the detailed hypotheses are contained in Table 1.

The analysis of the detailed hypotheses allowed to single out relationships between the variables of family businesses in Poland.

The first of the detailed hypotheses assumed a relationship between the family firm internationalization nature and the age of a business. No relationship with the age of

\footnotetext{
${ }^{1}$ The minimum sample was 383 firms, with $\alpha=0.05, b=0.05$ and $p=0.5$.

2 The CATI method was used to conduct research with 75 respondents.

${ }^{3}$ The PAPI method was used to conduct research with 67 respondents.

${ }^{4}$ The CAll method was used to conduct research with 280 respondents.
} 
a business was recorded either in the case of internationalization ad hoc or planned internationalization strategy (H.1). Common observations of family businesses and their decision-making processes may indicate another type of behaviour, e.g. 'consuming' profit in the first years of business operation. Statistical results unequivocally exclude the influence of this independent variable on the internationalization nature.

Table 1. Test results for auxiliary hypotheses

\begin{tabular}{|c|c|l|c|c|c|c|}
\hline \multicolumn{2}{|c|}{ auxiliary hypothesis } & relationship between & chi-squared test & $\mathbf{d f}$ & $\mathbf{p}$ & V-Cramer \\
\hline \multirow{2}{*}{ H.1 } & 1.1 & IS-PS/AB & 19.583 & 15 & 0.189 & 0.124 \\
\cline { 2 - 7 } & 1.2 & IS-AH/AB & 21.457 & 15 & 0.123 & 0.112 \\
\hline \multirow{2}{*}{ H.2 } & 2.1 & IS-PS/SB & 50.702 & 15 & $<0.001$ & 0.256 \\
\cline { 2 - 7 } & 2.2 & IS-AH/SB & 18.87 & 15 & 0.220 & 0.023 \\
\hline \multirow{2}{*}{ H.3 } & 3.1 & IS-PS/IP & 63.216 & 25 & $<\mathbf{0 . 0 0 1}$ & 0.173 \\
\cline { 2 - 7 } & 3.2 & IS-AH/IP & 24.363 & 25 & 0.498 & 0.012 \\
\hline \multirow{2}{*}{ H.4 } & 4.1 & IS-PS/EE & 45.026 & 20 & $\mathbf{0 . 0 0 1 2}$ & 0.238 \\
\cline { 2 - 7 } & 4.2 & IS-AH/EE & 46.726 & 20 & $\mathbf{0 . 0 0 1}$ & 0.216 \\
\hline \multirow{2}{*}{ H.5 } & 5.1 & IS-PS/ VA-GM & 46.398 & 25 & $\mathbf{0 . 0 0 6}$ & 0.259 \\
\cline { 2 - 7 } & 5.2 & IS-AH/ VA-GM & 19.365 & 25 & 0.0779 & 0.121 \\
\hline
\end{tabular}

$(\alpha=0.05 ; n=420)$

Source: own study.

The second hypothesis emphasised the relationship between the analysed variable and the size of a business. The obtained results of statistical testing indicate the lack of relationship between family firm internationalization nature and the size of a business (H.2.2). However, in the case of activities connected with planned internationalization strategy, there is a link with the size of a business (H.2.1). It means that businesses along with their development invest profit earned (or part of it) into progressive measures.

Another testing area comprised relationships between the analysed dependent variables and the family propensity to act autonomously. A relationship between family firm internationalization nature and planned internationalization strategy and the propensity to act autonomously was confirmed (H.3.1). At the same time, the hypothesis regarding interdependency between family firm internationalization nature to internationalization ad hoc and the propensity to act autonomously in the business sphere was rejected (H.3.2). It testifies to family enterprise owners' and managers' business maturity.

The detailed hypothesis assumed a relationship between family firm internationalization nature and the family willingness to innovate and take risks. Testing the hypothesis revealed that both in the first case (planned internationalization strategy) and the second case (internationalization ad hoc) there is a connection with the willingness to innovate and take risks (H.4). Innovation in this context refers to the creative capacity, and the necessary flexibility and knowledge, to adapt to new markets and to personalise the offered solutions.

The hypothesis H.5 concerned the analysis of the relationship between family firm internationalization nature and proactiveness relative to marketplace opportunities. The existence of relationships between family firm internationalization nature and family proactiveness relative to marketplace opportunities was confirmed. It may mean that the more valuable assets for family business are assigned for foreign market the more intention there is in a company to strategically plan the internationalization process. 
The main hypothesis concerning activities connected with the family firm internationalization nature in both planned internationalization strategy and internationalization ad hoc was confirmed. In accordance with the results, it can be stated that family entrepreneurs treat internationalization, regardless of whether they plan it or do it ad hoc, as company development possibility. The results of a multiple analysis therefore entitle to believe that, firstly, Polish owners of family businesses show high awareness and maturity in terms of the need of the company's internationalization activities, and secondly: having regard to internationalization factors associated with the company's family nature should be regarded as fulfilled.

Table 2. Results of testing the main hypothesis

\begin{tabular}{|c|c|c|c|c|c|}
\hline \multirow{2}{*}{ The main hypothesis } & relationship between & chi-squared test & $\mathbf{d f}$ & $\mathbf{p}$ & V-Cramer \\
\cline { 2 - 6 } & PA-B/PA-F & 215.7982 & 25 & $<0.001$ & 0.34 \\
\hline
\end{tabular}

$(\alpha=0.05 ; n=420)$

Source: own study.

\section{CONCLUSIONS}

This study focuses on the evaluation of entrepreneurship orientation as the main resource of the internationalization nature of family businesses from Poland, and measured it through the four elements proposed by Covin and Slevin (1989): Innovation, Proactivity, Autonomy and Risk. The research provides evidence of a higher degree of EO in the behaviour of the families of the surveyed companies that were successful in the international market. There is not much difference regarding the level of autonomy. This factor is especially relevant in small companies, in which the firm is an extension of its leader. In these organisations it is common that the director has a tendency to want to be responsible for all decisions and tasks, and has difficulty delegating. The study shows that companies which do not internationalize have mainly implemented changes within their organisations, while successful ones have emphasized changes enabling the adaptation of their services to their clients. It is interesting that all family owned businesses from the research refer to their lack of financial resources, and this is probably an important factor which limits investments which may involve significant risk, because they could endanger the survival of the company. The difference found is that some companies admit that they started their internationalization only because they could use government assistance by entering an export promotion programme. The different motivation for internationalization can also be judged as a different level of proactivity. Most surveyed family companies started their expansion in foreign markets as a strategic decision, prior to the economic crisis, which reinforced their proactive behaviour. These results are in accordance with Alon and Higgins (2005) who consider that successful international companies are proactive and can respond to particular foreign environments. According to Wach (2017), 'the role of the family in international entrepreneurship seems to be still unexplored and needs further detailed research studies'. That is why, this study focuses on an important yet under-researched topic, the internationalization nature of Polish family owned businesses. The likely shortage of human and financial resources for these companies, together with service inseparability, drives them to develop other intangible resources. After using three complementary strategies to ensure internal validity (literature 
research, pattern matching, and theory triangulation), the results show that, as hypothesised, one of these resources, EO, must be considered the key for the internationalization process. Regarding proactivity, research shows that successful companies do not just react to events. They foresee future scenarios and have a long-term plan in order to be better prepared. They started international expansion in a favourable economic context and therefore could proactively choose the most appropriate timing and allocate the necessary resources. The level of risk taking is in general low for all the companies studied. This attitude is reflected in the fact that companies only ventured internationally when they perceived that they were sufficiently secure. Low level of risk taking is very characteristic for family owned businesses. This is connected with the desire to protect family and the desire to pass the family company to the next generations.

There is no research about family entrepreneurship orientation and its influence on internationalization. However, there is research about family ownership and its impact on the internationalization process. The research results are in line with the survey conducted by Morono, Monreal-Perez and Sanchez-Marin (2015). They found that in Spanish firms the family experience positively affects internationalization. On the other hand, the presented research is inconsistent with result of Daszkiewicz and Wach (2014) or Fernandez and Nieto which evidenced that internationalization is negatively related to family ownership. The answer to this inconsistency may lay in construct of family and family members entrepreneurship orientation. This, for sure, need more in depth research.

The main hypothesis, verified during the interpretation of statistical data, points to the ability of Polish owners of family businesses to internationalize in a strategic and planned way. Moreover, a few dependencies were proven to be linked to the analysed variable:

1. The bigger the business, the more often profit is earmarked for business development and to the strategic internationalization process.

2. Innovative (or aspiring to be innovative) businesses earmark profit for business development more often and to the strategic internationalization process.

3. Entrepreneurship orientation seen as the propensity to act autonomously, the willingness to innovate and take risks and proactiveness relative to market opportunities, is tied with an open and planned attitude to the internationalization process.

4. The more proactive the owner is the more often internationalization process is carefully planned.

To summarise, these results show that, although all five EO dimensions may be important for the international success of SMEs, they are not all equally relevant. What can be also deduced from the research is that the surveyed Polish family owned businesses when they internationalize, they not only have high level of entrepreneurship orientation, but they also have challenge-oriented culture which means that such companies are oriented towards new ventures, new relations, new solutions and new markets. But, they plan new challenges using the strategic approach.

The study allowed to observe the relations that may be important for policy makers, family business owners, managers in family businesses and advisors. First of all, the family has a significant influence on the choice of the internationalisation strategy. The results show that for service SMEs, the entrepreneurship qualities of their leaders are a critical resource, because he/she has high interaction with primary activities. Therefore, family 
business owners should understand that these aspects are crucial for their success on international markets. Family business owners need to develop strategic competencies, such as: analysing the competition, positioning their companies in the market, setting goals and final results, as well as building action plans and applying control systems. This study focuses on a field in which there is a general consensus that there is a need for more research. In order to enhance the strength of the conclusions obtained, further studies could extend the present work by the use of larger samples. Also, carrying out similar studies in different geographical areas (regions or countries), especially in the CEE region, could be interesting to compare the results. The biggest limitation of the research is that it is not representative and the results cannot be generalised for the whole population of family owned businesses in Poland. The second limitation is that the result presented in the article are from a pilot study and they will be extended in the future.

\section{REFERENCES}

Aharoni, Y. (1966). The foreign investment decision process. Boston: Division of Research, Graduate School of Business Administration, Harvard University.

Barney, J.B. (2011). The Future of Resource-Based Theory: Revitalization or Decline?. Journal of Management, 37(5), 1299-1315. https://doi.org/10.1177/0149206310391805

Barney, J. (1991). Firm resources and sustained competitive advantage. Journal of Management, 44(1), 99-120. https://doi.org/10.1177/014920639101700108

Bednarz, J., Bieliński, T., Nikodemska-Wolowik, A.M., \& Otukoya, A. (2017). Sources of the Competitive Advantage of Family Enterprises: An International Approach Focusing on China, Nigeria and Poland. Entrepreneurial Business and Economics Review, 5(2), 123-142. https://doi.org/10.15678/EBER.2017.050207

Björnberg, Å., \& Nicholson, N. (2012). Emotional Ownership, The Next Generation's Relationship With the Family Firm. Family Business Review, 25(4), 374-390. https://doi.org/10.1177/0894486511432471

Buckley, P.J. (1999). Foreign direct investment by small and medium sized enterprises: The theoretical background. In P.J. Buckley \& P.N. Ghauri (Eds.), The Internationalization of the Firm. NY: International Thomson Business Press.

Byrom, J., \& Lehman, K. (2009). Coopers Brewery: Heritage and innovation within a family firm. Marketing Intelligence \& Planning, 27, 516-523. https://doi.org/10.1108/02634500910964074

Calabrò, A., Mussolino, D., \& Huse, M. (2009). The role of board of directors in the internationalisation process of small and medium sized family businesses. International Journal of Globalisation and Small Business, 3(4), 393-411. https://doi.org/10.1504/IJGSB.2009.032259

Carr, C., \& Bateman, S. (2009.) International strategy configurations of the world's top family firms. Management International Review, 49(6), 733-758. https://doi.org/10.1007/s11575-009-0018-3

Child, J., Hong Ng, S., \& Wong, C. (2002). Psychic distance and internationalization. International Studies of Management \& Organization, 39(1), 36-56.

Claver, E., Rienda, L., \& Quer, D. (2007). The internationalization process in family firms: Choice of market entry strategies. Journal of General Management, 33(1), 1-14. https://doi.org/10.1177/030630700703300101

Claver, E., Rienda, L., \& Quer, D. (2009). Family firms' international commitment: The influence of family related factors. Family Business Review, 22(2), 125-135. https://doi.org/10.1177/0894486508330054 
Coviello, N., \& Munro, H. (1997). Network relationships and the internationalization process of small software firms. International Business Review, 6(4), 361-386. https://doi.org/10.1016/S0969-5931(97)00010-3

Coviello, N.E., \& Munro, H.J. (1995). Growing the entrepreneurial firm: Networking for international market development. European Journal of Marketing, 29(7), 49-61. https://doi.org/10.1108/03090569510095008

Covin, J.G., \& Slevin, D.P. (1991). A conceptual model of entrepreneurship as firm behavior. Entrepreneurship Theory and Practice, 16(1), 7-25.

Dana, L., Welpe, I.M., \& Ratten, V. (2008). Handbook of Research in European Business and Entrepreneurship: Towards a Theory of Internationalization. Cheltenham: Edward Elgar Publishing Limited.

Davis, P.S., \& Harveston, P.D. (2000). Internationalization and organizational growth: The impact of internet usage and technology involvement among entrepreneur led family businesses. Family Business Review, 13(2), 107-120. https://doi.org/10.1111/j.1741-6248.2000.00107.x

Daszkiewicz, N., \& Wach, K. (2014). Motives for Going International and Entry Modes of Family Firms in Poland. Journal of Intercultural Management, 6(2), 5-18. https://doi.org/10.2478/joim-2014-0008

De Chiara, A., \& Minguizzi, A. (2002). Success factors in SMEs' internationalization processes: An Italian investigation. Journal of Small Business Management, 40(2), 144-153. https://doi.org/10.1111/1540-627X.00046

Donckels, R., \& Fröhlich, E. (1991). Are family businesses really different? European experiences from STRATOS. Family Business Review, 4(2), 149-160. https://doi.org/10.1111/j.1741-6248.1991.00149.x

Erdener, C., \& Shapiro, D.M. (2005). The internationalization of Chinese family enterprises and Dunning's eclectic MNE paradigm. Management and Organization Review, 1(3), 411-436. https://doi.org/10.1111/j.1740-8784.2005.00021.x

Fernandez, Z., \& Nieto, M.J. (2005). Internationalization strategy of small and medium-sized family businesses: Some influential factors. Family Business Review, 18(1), 77-90. https://doi.org/10.1111/j.1741-6248.2005.00031.x

Fernández, Z., \& Nieto, M.J. (2006). Impact of ownership on the international involvement of SMEs. Journal of International Business Studies, 37, 340-351.

Figueira-de-Lemos, F., Johanson, J., \& Vahlne, J. (2011). Risk management in the internationalization process of the firm: A note on the Uppsala model. Journal of World Business, 46(2), 143-153.

Flören, R. (2001). Internationalization of family business in the Netherlands: Research results about implementation of new international strategies and barriers to growth in international markets. In BDO Accountants and Advisors. Breukelen, Netherlands: University of Nyenrode.

Gallo, M.A., \& Pont, C.G. (1996). Important factors in family business internationalization. Family Business Review, 9(1), 45-59. https://doi.org/10.1111/j.1741-6248.1996.00045.x

Gallo, M.A., \& Sveen, J. (1991). Internationalizing the family business: Facilitating and restraining factors. Family Business Review, 4(2), 181-190. https://doi.org/10.1111/j.1741-6248.1991.00181.x

Gallo, M.A., \& Estapè, M.J. (1992). Internationalization of the family business (Research paper no. 230), Barcelona, Spain: IESE Business School.

Gallo, M.A., \& Garcia-Pont, C. (1996). Important factors in family business internationalization. Family Business Review, 9(1), 45-59. https://doi.org/10.1111/j.1741-6248.1996.00045.x

Gallo, M.A., \& Sveen, J. (1999). Internationalizing the family business: Facilitating and restraining factors. Family Business Review, 4(2), 181-190. https://doi.org/10.1111/j.1741-6248.1991.00181.x

Gankema, H.G.J., Snuif, H.R., \& Van Dijken, K.A. (1997). The internationalization process of small and medium sized enterprises: An evaluation of the stage theory. In R. Donckels \& A. Miettinen 
(Eds.), Entrepreneurship and SME research: On its way to the next millennium (pp. 185-197). Aldershot: Ashgate Publishing.

Gaweł, A. (2013). Entrepreneurship - A Theorethical Approach. In M. Rekowski (Ed.), Enterpreneurial Tisuue and Regional Economy: Case Studies of Selected Polish and Spanish Regions (chapter 1). Poznań, Poland: The Poznań University of Economics Publishing House.

Gimeno, J., Folta, T.B., Cooper, A.C., \& Woo, C.Y. (1997). Survival of the fittest? Entrepreneurial human capital and the persistence of underperforming firms. Administrative Science Quarterly. 42(4), 750-783. https://doi.org/10.2307/2393656

Graves, C., \& Thomas, J. (2004). Internationalisation of the family business: A longitudinal perspective. International Journal of Globalisation and Small Business, 1(1), https://doi.org207223.10.1504/IJGSB.2004.005615

Graves, C., \& Thomas, J. (2006). Internationalization of Australian family businesses: A managerial capabilities perspective. Family Business Review, 19(3), 207-224. https://doi.org/10.1111/j.1741-6248.2006.00066.x

Graves, C., \& Thomas, J. (2008). Determinants of the internationalization pathways of family firms: An examination of family influence. Family Business Review, 21(2), 151-167. https://doi.org/10.1111/j.1741-6248.2008.00119.x

Hadryś-Nowak, A. (2013). Determinanty form ekspansji zagranicznej przedsiębiorstw rodzinnych, wyd. I, Poznań, Poland: Oficyna Wydawnicza G\&P.

Hashai, N. (2011). Sequencing the expansion of geographic scope and foreign operations by "born global" firms. Journal of International Business Studies, 42(1), 995-1015.

Johanson, J., \& Vahlne, J. (1977). The internationalization process of the firm: A model of knowledge development and increasing foreign market commitments. Journal of International Business Studies, 8(1), 23-32. https://doi.org/10.1057/palgrave.jibs.8490676

Johanson, J., \& Vahlne, J. (2006). Commitment and opportunity development in the internationalization process: A note on the Uppsala internationalization process model. Management International Review, 46(2), 165-178. https://doi.org/10.1007/s11575-006-0043-4

Karagozoglu, N., \& Lindell, M. (1998). Internationalization of small and medium sized technology based firms: An exploratory study. Journal of Small Business Management, 36(1), 44-59.

Khemakhem, R. (2010). Explaining the entry mode choice among Tunisian exporting firms: Development and test of an integrated model. European Journal of Marketing, 44(1/2), 223-244. https://doi.org/10.1108/03090561011008682

Kim, D., Kandemir, D., \& Cavusgil, T.S. (2004). The role of family conglomerates in emerging markets: What western companies should know. Thunderbird International Business Review, 46(1), 13-38.

Knight, G., \& Kim, D. (2009). International business competence and the contemporary firm. Journal of International Business Studies, 40(2), 255-273.

Knight, G., \& Cavulgil, S.T. (1996). The born-global firm: a challenge to traditional internationalization theory. In Advances in International Marketing (pp. 11-26). New York, NY: JAI Press.

Koch, A.J. (2001). Factors influencing market and entry mode selection: developing the MEMS model. Marketing Intelligence \& Planning, 19(5), 351-361.

Kontinen, T., \& Ojala, A. (2010b). Internationalization pathways of family SMEs: Psychic distance as a focal point. Journal of Small Business and Enterprise Development, 17(3), 437-454. https://doi.org/10.1108/14626001011068725

Kontinen, T., \& Ojala, A. (2012a). Internationalization pathways among family-owned SMEs. International Marketing Review, 29(5), 496-518. https://doi.org/10.1108/02651331211260359 
Kostova, T., \& Roth, K. (2002). Adoption of an organizational practice by subsidiaries of multinational corporations: Institutional and relational effects. Academy of Management Journal, 45(1), 215-233. https://doi.org/10.5465/3069293

Leonidou, L. (2004). An analysis of the barriers hindering small business export development. Journal of Small Business Management, 42(3), 279-302. https://doi.org/10.1111/j.1540-627X.2004.00112.x

Lewandowska, A., Więcek-Janka, E., Hadryś-Nowak, A., Wojewoda, M., \& Tylczyński, Ł. (2016). Firma rodzinna to marka. Poznań: Instytut Biznesu Rodzinnego.

Lin, W.-T. (2012). Family ownership and internationalization processes: Internationalization pace, internationalization scope, and internationalization rhythm. European Management Journal, 30(1), 47-56. https://doi.or/10.1016/j.emj.2011.10.003

Lu, J., \& Beamish, P. (2001). The internationalization and performance of SMEs. Strategic Management Journal, 22(6-7), 565-586. https://doi.org/10.1002/smj.184

Lumpkin, G.T., \& Dess, G.G. (1996). Clarifying the entrepreneurial orientation construct and linking it to performance. Academy of Management Review, 21(1), 135-172. https://doi.org/10.2307/258632

Manolova, T.S., Brush, C.G., Edelman, L.R., \& Greene, P.G. (2002). Internationalization of small firms: Personal factors revisited. International Small Business Journal, 20(1), 9-31. https://doi.org/10.1111/j.1741-6248.2006.00066.x

McDougall, P.P., \& Oviatt, B.M. (1996). New venture internationalization, strategic change, and performance: A follow-up study. Journal of Business Venturing, 11(1), 23-40. https://doi.org/10.1016/0883-9026(95)00081-X

McKibbin, P., \& Pistrui, D. (1997). East meets west: Innovative forms of foreign trade finance between Italian family enterprises and emerging SMEs in Romania. Family Business Review, 10(3), 63-280.

Menéndez-Requejo, S. (2005). Growth and internationalization of family businesses. International Journal of Globalisation and Small Business, (1), 122-133.

Miller, D. (1983). The correlates of entrepreneurship in three types of firms. Management Science, 29(7), 770-791. https://doi.org/10.1287/mnsc.29.7.770

Merono, F., Monreal-Perez, J., \& Sanchez-Marin, G. (2015). Family SMEs' Internationalisation: Disentangling the Influence of Familiness on Spanish Firms' Export Activity. Journal of Small Business Management, 53(4), 1164-1184. https://doi.org/10.1111/jsbm.1211

Muñoz-Bullón, F., \& Sánchez-Bueno, M.J. (2012). Do family ties shape the performance consequences of diversification? Evidence from the European Union. Journal of World Business, (47), 469-477.

Oesterle, M.J., Richta, H., \& Fish, J. (2013). The influence of ownership structure on internationalization. International Business Review, (22), 187-201.

Okoroafo, S.C. (1999). Internationalization of family businesses: Evidence from northwest Ohio, U.S.A. Family Business Review, 12, 147-158. https://doi.org/10.1111/j.1741-6248.1999.00147.x

Olivares-Mesa, A., \& Cabrera-Suárez, K. (2006). Factors affecting the timing of the export development process: Does the family influence on the business make a difference?. International Journal of Globalisation and Small Business, (1), 326-339.

Pangarkar, N. (2008). Internationalization and performance of small-and medium-sized enterprises. Journal of World Business, 43(2008), 475-485.

Porter, M.E. (1991). Towards a dynamic theory of strategy. Strategic Management Journal, (12), 95117. https://doi.org/10.1002/smj.4250121008

Qian, G. (2002). Multinationality, product diversification and profitability of emerging US small and medium sized enterprises. Journal of Business Venturing, 17, 611-633. 
Sciascia, S., Mazzola, P., Astrachan, J.H., \& Pieper, T.M. (2012b). The role of family ownership in international entrepreneurship: Exploring nonlinear effects. Small Business Economics, 38(1), 15-31. https://doi.org/10.1007/s11187-010-9264-9

Shuman, J.C., \& Seeger, J.A. (1986). The Theory and Practice of Strategic Management in Smaller Rapid Growth Firms. American Journal of Small Business, 11(1), 7-18. https://doi.org/10.1177/104225878601100101

Tsang, E.W.K. (2001). Internationalizing the family firm: A case study of a Chinese family business. Journal of Small Business Management, 39(1), 88-94. https://doi.org/10.1111/0447-2778.00008

Tsang, E.W.K. (2002). Learning from overseas venturing experience: The case of Chinese family businesses. Journal of Business Venturing, 17(1), 21-40. https://doi.org/10.1016/S0883-9026(00)00052-5

Van de Ven, A.H., \& Poole, M.S. (1995). Explaining development and change in organizations. Academy of Management Review, 20(3), 510-540. https://doi.org/10.2307/258786

Wach, K. (2015). Entrepreneurial Orientation and Business Internationalisation Process: The Theorethical Foundations of International Entrepreneurship. Entrepreneurial Business and Economics Review, 3(2), 9-24. https://doi.org/10.15678/EBER.2015.030202

Wach, K. (2017). Exploring the Role of Ownership in International Entrepreneurship: How does Ownership Affect Internationalisation of Polish Firms?. Entrepreneurial Business and Economics Review, 5(4), 205-224. https://doi.org/10.15678/EBER.2017.050410

Wach, K., \& Wojciechowski, L. (2014). The Size and the Strategic International Orientation: The Use of EPRG Model among Polish Family and Non-Family Firms. Przedsiębiorczość i Zarzq̨dzanie, XV(7), 143-156.

Welch, L.S., \& Luostarinen, R. (1988). Internationalization: Evolution of a concept. Journal of General Management, 1(2), 34-55.

Westhead, P., Wright, M., \& Ucbasaran, D. (2001). The internationalization of new and small firms: A resource-based view. Journal of Business Venturing, 16(4), 333-358. https://doi.org/10.1016/\$0883-9026(99)00063-4

Więcek-Janka, E. (2015). The Essentials of Marketing Research. Poznań, Poland: Publishing House of Poznan University of Technology.

Wolff, A.J., \& Pett, T.L. (2000). Internationalization of small firms: An examination of export competitive patterns, firm size, and export performance. Journal of Small Business Management, 38(2), 34-47.

Yeung, H.W.-C. (2000). Limits to the growth of family owned business? The case of Chinese transnational corporations from Hong Kong. Family Business Review, 13(1), 55-70. https://doi.org/10.1111/j.1741-6248.2000.00055.x

Yip, G.S., Biscarri, J.G., \& Monti, J.A. (2000). The role of the internationalization process in the performance of newly interantionalizing firms. Journal of International Marketing, 8(3), 10-35. https://doi.org/10.1509/jimk.8.3.10.19635

Zahra, S.A, Ireland, R.D., \& Hitt, M.A. (2000). International expansion by new venture firms: International diversity, mode of market entry, technological learning, and performance. Academy of Management Journal, 43(5), 925-950. https://doi.org/10.2307/1556420

Zahra, S.A. (2003). International expansion of U.S. manufacturing family businesses: The effect of ownership and involvement. Journal of Business Venturing, 18(4), 495-512. https://doi.org/10.1016/S0883-9026(03)00057-0 


\section{Author}

\section{Alicja Hadryś-Nowak}

Adjunct at International Management Chair, Poznań University of Economics and Business. PhD in economics specialist in family business management, internationalization and branding. Author of several book chapters and over scientific articles. Visiting Professor at Lethbridge University in Canada, Jonkoping International Business School in Sweden and Politecnica della Marche in Italy. Expert in PARP, European Commission and IBR (Instytut Biznesu Rodzinnego). Team member in several European grants and projects.

Correspondence to: Alicja Hadryś-Nowak, Poznań, University of Economics, al. Niepodległości 10,61-875 Poznań, Poland, e-mail: alicja.hadrys@ue.poznan.pl

\section{Acknowledgements and Financial Disclosure}

The author would like to thank the anonymous referees for their useful comments, which allowed to increase the value of this article.

\section{Copyright and License}

This article is published under the terms of the Creative Commons

Attribution - NoDerivs (CC BY-ND 4.0) License

http://creativecommons.org/licenses/by-nd/4.0/

Published by the Centre for Strategic and International Entrepreneurship - Krakow, Poland 
